\title{
African Journal of Traditional, Complementary and Alternative Medicines
}

\author{
$\underline{\text { www.africanethnomedicines.net }}$
}

The African Journal of Traditional, Complementary and Alternative Medicines (AJTCAM), a new broad-based journal, is founded on two key tenets: To publish exciting research in all areas of applied medicinal plants, Traditional medicines, Complementary Alternative Medicines, food and agricultural technologies, and promotion of healthy use of medicinal products. Secondly, to provide the most rapid turn-around time possible for reviewing and publishing, and to disseminate the articles freely for teaching and reference purposes. All articles published in AJTCAM are peer-reviewed.

The African Journal of of Traditional, Complementary and Alternative Medicines is published thrice a year, and is online.

\section{Types of paper}

Regular articles: These should describe new and carefully researched findings that have arisen from experimental procedures. The articles should be given in sufficient detail for others to verify the work. Authors should submit data that have arisen from animal and human studies in an ethically proper way by following guidelines as set by the World Health Organization. Papers that violate these principles will not be accepted.

Short Communications: A Short Communication is suitable for recording the results of complete small investigations or giving details of new models or hypotheses, chemical isolation and identification, innovative methods, techniques, clinical trials and epidemiological studies.

Reviews: Submissions of reviews and perspectives covering topics of current interest are welcome and encouraged. reviews are also peer-reviewed. 


\title{
Editors-in-Chief:
}

Clement O. ADEWUNMI, Drug Research and Production Unit, Faculty of pharmacy, Obafemi Awolowo University, Ile-Ife, Nigeria

John A. O. OJEWOLE, Department of Pharmacology, faculty of Health Sciences, University of KwaZulu-Natal, Private Bag X54001, Durban 4000, South Africa E-mail: editor@africanethnomedicines.net or cadewumi@yahoo.com or ojewolej@ukzn.ac.za

\section{Editorial Advisory Board:}

\author{
Prof. Memory ELVIN-LEWIS - USA \\ Prof Siegfried E. DREWES - S. Africa \\ Prof. George J. AMABEOKU - S. Africa \\ $\mathrm{Dr}$. Mohammed Ali MAHESAR - Pakistan \\ Prof. Anthony A. ELUJOBA - Nigeria \\ Prof. Karniyus S. GAMANIEL - Nigeria \\ Prof. Bonaventure T. NGADJUI - Cameroon \\ Prof. C. T. MUSABAYANE - Zimbabwe \\ Prof. Marian ADDY - Ghana \\ Prof. Alain TOUWAIDE - USA \\ Dr. Noor R. Abdullah - Malaysia \\ Dr. Elaine Elisabetsky - Brazil \\ Prof. Jose L. MARTINEZ - Chile \\ Prof. Wilhelm BECKER - Germany \\ Dr. Kelly BANNISTER - Canada \\ Prof. I. Pierre GUISSOU - Burkina-Faso
}

